\title{
Arnold Schoenberg amidst the struggle between scientific materialism and spiritual revival
}

\author{
Tristan Guillermo Torriani \\ Universidade Estadual de Campinas, Faculdade de Ciências Aplicadas \\ tristan.torriani@fca.unicamp.br
}

\begin{abstract}
Post-war historiography has downplayed the spiritual dimension of modernist artists in order to present their work more favorably in a culture overwhelmed by scientific materialism. Drawing from several sources, this paper reconstructs an interpretation of the context which Schoenberg had to contend with as an artist. The first section sets the stage for understanding the struggle between scientific materialism and movements of spiritual revival. The second section deals directly with Schoenberg's case and addresses not only the criticisms directed against his music, but also tries to shed light on his problematic relation with Adorno and Thomas Mann. The concluding section argues that although the public's perception of Schoenberg may be associated to twelve-tone technique, as a composer, the creation of a realm beyond tonality also had a religious and spiritual dimension that is still insufficiently acknowledged.
\end{abstract}

Keywords: Arnold Schoenberg, Scientific Materialism, Spirituality, Dodecaphony, Impure a priori.

\section{Arnold Schoenberg e o conflito entre o materialismo científico e a renovação espiritual}

Resumo: A historiografia do pós-guerra minimizou a dimensão espiritual dos artistas modernistas a fim de apresentar o seu trabalho de forma mais favorável em uma cultura dominada pelo materialismo científico. Partindo de fontes diversas, este trabalho reconstrói uma interpretação do contexto com o qual Schoenberg, como artista, teve que se confrontar. A primeira seção estabelece o cenário para a compreensão do confronto entre o materialismo científico e os movimentos de renovação espiritual. A segunda seção trata diretamente do caso de Schoenberg e aborda não apenas as críticas dirigidas contra sua música, mas também tenta esclarecer sua problemática relação com Adorno e Thomas Mann. A seção final argumenta que, embora a percepção pública de Schoenberg possa ser talvez mais associada à técnica dodecafônica, como compositor, a criação de um espaço para além da tonalidade possuía para ele também uma dimensão religiosa e espiritual que ainda permanece insuficientemente reconhecida.

Palavras-chave: Arnold Schoenberg, Materialismo Científico, Espiritualidade, Dodecafonismo, A priori impuro.

\section{Introduction}

Few can sincerely dispute that the turn of the $20^{\text {th }}$ century brought about a watershed change in the musical lifeworld (HABERMAS, 1981) and soundscape (SHAFER, 1994). Whether the end of the common practice period around 1910 is experienced at the subjective level as a tragedy or a liberation, no person interested in music can avoid contending with its ramifications. Some of them run so deep and reach so far that even the very idea of addressing them in a balanced manner might trigger a vertigo attack. A better approach seems to be focusing on a major actor in this process and to hope to gain 
insight into what motivated his or her attempt to transcend established tonal composition. Again, hardly anyone can contest that Arnold Schoenberg is, side by side with Igor Stravinsky, one such major figure. So, for what it is worth, we can agree on at least these two things and use them as a starting point to try to make sense of the post-tonal musical lifeworld.

When we consider Schoenberg, we find yet another point of agreement in that his name has been closely associated to a technical innovation. However, recent scholarship indicates that, most of the time, this view misses a crucial spiritual dimension underlying his motivation. Post-war historiography has downplayed the spiritual dimension of modernist artists in order to present their work more favorably in a culture dominated by scientific materialism. Drawing from several sources, this paper reconstructs an interpretation of the context which Schoenberg as an artist had to contend with.

The first section sets the stage for understanding the struggle between scientific materialism and movements of spiritual revival. The second section deals directly with Schoenberg's case and addresses not only the criticisms directed against his music, but also tries to shed light on his problematic relation with Adorno and Thomas Mann. The concluding section argues that although the public's perception of Schoenberg may be strongly associated to twelve-tone technique, as a composer, the creation of a realm beyond tonality had a religious and spiritual dimension that is still insufficiently appreciated.

\section{Defining the Struggle between Matter and Spirit}

It is generally recognized that philosophical disputes cannot be solved without giving special attention to the definition of concepts. The reason for this is that Philosophy uses discursive intellect to clarify the very conceptual frameworks we need to interpret reality. When we experience a sensation or perceive an external object such as 'viola' and want to refer to it, we need to use a term by following a rule that other speakers can supervise. If this condition is not respected, we cannot attribute the possession of a concept for the sensation or perception to a speaker (ROS, 1990). Philosophical disputes often arise because speakers disagree on how the terminology they want to use should be defined. It is important to realize that without verbal language the very concept of 
discursive intellect becomes impossible. In addition, without pre-existing concepts, it is impossible to interpret phenomena. Therefore, Kant's concept of the a priori $^{l}$ is indispensable to distinguish between a thing and its concept (MOSER, 1987). However, Piaget's empirical studies of children's cognitive development and Wittgenstein's later focus on natural language ${ }^{2}$ have provided strong arguments against the thesis that the $a$ priori is pure $^{3}$. Kant himself recognized the concept of an impure a priori, which he associated to variable and concrete empirical concepts (such as the concept of a dog). His former student Herder made important steps towards a linguistic interpretation of the $a$ priori, but this crucial insight was lost under the enormous weight Kant placed on the pure a priori. This polarized the debate because it pitted pure apriorism against empiricists (later joined by a disaffected Herder) who realized that concept construction could not occur in a pure vacuum and that experience had to play at least some role in the process.

Current debates in the philosophy of science tend to emphasize empirical knowledge, or what Kant called the a posteriori and, following Quine (MOSER, 1987), use the term 'naturalism' in an epistemological context to avoid the rigid concept of the pure a priori. However, this has led to a general reluctance to mention the a priori at all, which is counterproductive because it deprives us of the distinction between the concept and the thing. A further complication is caused by the need to avoid identifying concepts with mental images or representations. According to the representationalist view

\footnotetext{
${ }^{1}$ German philosopher Immanuel Kant (1724-1804) introduced the distinction between knowledge that came directly from sense experience, which he called a posteriori because it happened later, from another type of knowledge that could not be clearly traced back to any sensation or perception. This second kind of knowledge was abstract or formal, and seemed to be already present before any concrete data could enter through our external senses. Kant proposed that this previous knowledge was required to structure our experience in a universal, necessary, and objective manner. He called it a priori because it was logically anterior to sensory experience. For example, when we look out into the world and see a long piece of wood, this is a posteriori knowledge. But to call it a piece of wood we need the concept of $<$ wood $>$. To understand that it is a didgeridoo, we also need the concept of $<$ didgeridoo $>$. To realize that a didgeridoo is a musical instrument, we need to acquire these concepts and they must all be given a priori, that is, before we perceive these objectcs, so that we can interpret the experience correctly.

${ }^{2}$ The expression 'natural language' is used to refer to any kind of human communication system that arose spontaneously for everyday life, as opposed to formal languages which were created for research in mathematics, logic, and artificial intelligence.

${ }^{3}$ According to Kant, the pure a priori contains absolutely no element from experience. A tautological statement, such as, "Music is music," can be accepted purely a priori according to some pre-defined definition of the concept of $<$ music $>$, as it respects the principle of identity, which is logical and cannot be extracted from sensory experience. However, the impure a priori is not so abstract and arises with at least some sensory input from our need to classify the experience of our daily lives.
} 
classically found in Locke's empiricist concept of an idea, concepts ought to somehow correspond to an externally perceived reality. However, this mirroring correspondence between a thing and its concept cannot be verified from an external point of view. To solve this, followers of Wittgenstein's later philosophy have sought, at the risk of being often misunderstood as nominalists, to argue for a concept of concept as a verbal categorization skill (ROS, 1990). This bypasses the whole aporia of mind-reality correspondence. Concepts cease to be either true or false as the propositions that contain them, but are rather regarded as legitimate classificatory proposals or not. The speech act in which a new concept is proposed, or an old one is revised, takes place in a normative sociolinguistic context. While scientific sociolinguistics may empirically map out categorization practices, it cannot establish or justify terminological rules without committing an is-ought fallacy.

When Schoenberg and other practitioners of twelve-tone technique are accused of intellectualism, it is absolutely indispensable to understand what is involved in the concept of the discursive intellect (BOULEZ, 1986). Unfortunately, this is a highly sophisticated epistemological topic that requires thorough decades-long reflection. To make things worse, the whole realm of deep intuition, which was central to influential early $20^{\text {th }}$ century figures such as Bergson, Husserl, Jung, Max Heindel and Rudolf Steiner, was left aside by mainstream Analytical Philosophy as it shifted its focus to natural or artificial languages. To a degree, this process replayed what happened in the early $19^{\text {th }}$ century, when Herder, notwithstanding his long-standing feud with Kant, took sides with him against Swedenborg, and explained away spiritual visions and communications as a self-deception caused by an unstable imagination.

In light of the foregoing discussion, this article proposes that the most tenable concept of the intellect is the one that does justice to its linguistic (Wittgenstein, Vygotsky), empirical (impure), developmental (Piaget), but also normative aspects. In agreement with these authors, we believe that Epistemology cannot be substituted by Psychology or Linguistics because these latter sciences harbor assumptions that need to be reflected upon by the former. The nature of this reflection is not factual, but rather normative, because it involves pondering values and interests. Facts regarding concept use or categorization skills are insufficient to establish rules that regulate how we ought to use classificatory terms. Our choice for certain conceptual frameworks cannot be 
justified solely on grounds of their supposed correspondence to reality, but must be admitted to lie in a matter of will. For example, Piaget broadened his concept of intelligence so as to be able to track cognitive development from the infant's sensorimotor stage onwards. In doing this he was guided by a cognitive interest because he thought that it could provide helpful insights. This is the most one can hope for in terms of rational justification at the deepest level.

The impure a priori is obstinately rejected by Kantian orthodoxy because it lacks the three desiderata of necessity, universality, and objectivity. However, according to authors such as Ros (1990), this can be shown to be a misunderstanding. Necessity, universality, and objectivity do not cease to either exist or to be possible in the new dispensation after the linguistic turn. What happens, however, is that they can only occur within a conceptual framework that has already been socially accepted as legitimate, such as basic arithmetic, for example (ROS, 1990). This has to be negotiated at the normative sociolinguistic level and cannot be imposed under the excuse of logical or metaphysical necessity. For this reason, argumentation within a conceptual framework continues to honor the principles of classical logic (identity, non-contradiction, excluded third). In contrast, argumentation towards the establishment of a new (or a revised) conceptual framework is weak and depends on good will of the speaking participants to consider alternative normative proposals. In other words, the crisis of foundations and rationality has been seriously overblown. Analytical philosophy of music, as practiced by Roger Scruton (1997) and many others, can help to dispel serious conceptual confusion that is often caused by theorists with a dogmatic bent and who are simply too impatient to reflect about their own assumptions.

Beyond this intellectual dimension of philosophical work, however, lies the deep intuition of moral metaphysical reality, which cannot be expressed in ordinary language, and rather requires the use of esoteric symbolism. Kant had already realized that the attempt to use the intellect (Verstand in German) in the sphere of moral metaphysics led to an undecidable dialectics that only the practical use of reason could overcome by invoking the existence of God, freewill and the immortality of the soul as necessary preconditions for moral life. Further limitations of the intellect were evinced by Heindel (2011) concerning the danger of two kinds of closed-mindedness. One type rejects all new ideas or information that conflicts with already held beliefs to avoid what Piaget 
called disequilibrium and Festinger called cognitive dissonance. The second type shuts persons off from any external source of information because it does not come from within. In more contemporary technical terminology, this phenomenon can be related to defeasible reasoning and non-monotonic logic. In the absence of hidden information, we may mistakenly conclude from unquantified statements such as 'Birds fly' and 'Penguins are birds' that 'Penguins fly'.

Historically, the narrowing down of discussions involving spirit and matter during the Scientific Revolution may have contributed to the establishment of a mechanistic worldview by eliminating concern for final causes (or teleology). Nevertheless, it would be disingenuous to deny the significant cognitive gains and benefits to humanity brought about by strategies such as literalism, specialization, simplification, reduction, and even outright elimination. Unfortunately, this advance was achieved by driving a wedge between science and religion and by sacrificing a rich and full ontology characteristic of the humanitarian ideals, such as, for example, those of the Rosicrucian Enlightenment (YATES, 1972). This may have paved the way for some personalities to dominate this fragmented landscape as venerated specialists. This modern dispensation contrasted starkly with some ancient philosophers' commitment to rounded personal development and to the preservation of an unbreakable bond between religion, philosophy, science, and the arts.

The irrationality of scientism ${ }^{4}$ has been also criticized from thinkers as different as Feyerabend (1975, 1978, 1996), Habermas (1981), Hacker (2009) and Scruton (1997). In contrast to science, scientism tries to invade what phenomenological sociologists as Habermas call the lifeworld and Shafer (1994) calls the soundscape with conceptual frameworks drawn from scientific research but which are woefully insensitive to the subtleties of the cultural and artistic phenomena they are distorting. In the philosophy of music, Scruton identifies the influence of scientism in the overemphasis on sound (an acoustic concept) as distinguished from tone (an aesthetic concept). Hacker warns against the mereological fallacy often committed by neuroscientists who attribute to a part, the

\footnotetext{
${ }^{4}$ The term 'scientism' is used here to encompass any view that seeks to extend methods, theories, and facts originally developed to investigate natural processes in the physical world to phenomena of the social and cultural world without doing justice to their higher degree of complexity, which includes the emergence of subjectivity.
} 
brain, acts which would be more properly attributed to the whole person. After a long period of involvement with scientific materialism, Feyerabend came to acknowledge the ideological character of science and the threat that it could pose in the hands of tyrannical elites.

In spite of this, scientific materialism remains influential because some dualistic mind-body theories have been shown to suffer from unsurmountable difficulties. Bunge (1981) argues that without a materialist ontology, significant advances in the areas of nuclear physics, molecular biology, life sciences, paleoanthropology would not have been possible. While owning the limitations of materialism in certain fields, he seeks to approach it from the perspective of formal logic and mathematics to make it fruitful for scientific research. Similar claims for the merits of materialism in the field of scientific psychology of music are legitimate. Hermann von Helmholtz (1821-1894) may be credited with having been a pivotal figure in this transition towards a greater acceptance of materialism, notwithstanding his reservations concerning metaphysics in general and Fichte's philosophy in particular, as described by Hatfield (2018). Subsequent developments led to the establishment in Germany of a powerful research tradition in the scientific psychology of music and music therapy (BRUHN, 1994, 2011).

Ros (2005) develops an interpretation of materialism that treats concepts for psychological states and abilities as attributes that can be predicated of animals and persons without conflicting with the concepts for their material components. He avoids Hacker's mereological fallacy by developing a multilayer approach. A physicalist conceptual framework is perfectly acceptable for minerals and machines. For an organism as an open system, however, a richer conceptual scheme must be superimposed so that the empirically observable processes can be fitted into an adequate explanatory scheme. As complexity increases through plants and animals, further layers are added till the level of what we would consider a person is reached. The possibility of superimposing increasingly complex conceptual frameworks and of providing transformational explanations between them enables us to affirm, at the same time and without great contradictions, that we have a material body and enjoy a mental life. In this sense, Ros defends an ontological materialism in which there is only one material substance (monism), but rejects conceptual materialism (reductionism and eliminativism) in which psychological concepts would be reduced to physical concepts or simply eliminated. 
Two difficulties with materialist theories based on normative sociolinguistics are that (a) they seek to draw support from our linguistic habits and (b) they privilege intersubjective validation over deep intuitive certainty. Hacker and Ros can argue against neuroscientists' mereological fallacy by drawing attention to the fact that we will generally say, "John drove the car" and not, "John's brain drove the car." Evolved human needs include, however, religious uses of language that require a spiritualist ontology, such as crying out, "Oh, my God!" Ros argues against the concept of a spirit as an autonomous substance that could survive the death of the body because, in his point of view, it commits a homunculus fallacy that leads to an infinite regress. From this intellectualist perspective, gnosis or deep intuitive certainty carry little or no weight. What matters is the possibility that other subjects can verify whether the concept of spirit can be unequivocally applied to some material or energetic configuration under empirical confirmation and replication. While it can be considered fair and good from a scientific perspective, it may also fail to meet the demands that evolution itself has inscribed in persons' souls throughout the ages and which are manifested in the positive energy provided by religion, spirituality, and moral metaphysics. The most philosophically sophisticated forms of materialism cannot avoid owning that their sphere of competence is restricted to what Heindel (2011) called the visible world, even if they indirectly infer or posit the existence of unobservable things, such as quantum particles. Moreover, their exoteric $^{5}$ character lays them open to defeasible reasoning because they lack occult esoteric information.

Yet another shortcoming of intellectualism may be the neglect for the heuristic power of symbolic analogies, similes and metaphors. A narrowed-down intellectualist mind may focus exclusively on literal meaning and logical relations. Heindel (1978) symbolically relates this technical prowess to biblical figures like Cain, whose agricultural offering was rejected by God because it contained an element of human intervention, whereas his brother Abel's lamb pleased Him because it was drawn directly from His creation. This archaic conflict between the spiritual descendants of Cain (Tubal Cain, the first blacksmith; Jubal Cain, inventor of music; Hiram Abif, master architect)

\footnotetext{
${ }^{5}$ Epicureanism, probably the most influential version of ancient materialism, was available to the public without requiring initiation in the Mysteries. Its stated purpose was to counter the crippling effects caused by the superstitious fear of death and of the gods. Its modern revival, particularly in the circle around Baron d'Holbach (1723-1789), was also directed to the public in the form of the Encyclopédie.
} 
and those of Abel's brother Seth (Solomon) can be said to live on to this very day in the dispute between the arts, sciences and intellectualistic philosophy on one hand, and religion and spirituality on the other hand. A reconciliation between both is needed, for the Cainians, despite their genius, may suffer from hubris, while the Sethians, despite their faith and piety, may remain ineffectual. Rudolf Steiner (1978) distinguishes between three major spiritual forces in the coming Aquarian age: Ahriman, which is strongly bound to matter; Lucifer, which misleads by overspiritualizing us; and Christ, which seeks to find a balance between both.

To appreciate how this symbolism can help us to overcome the struggle between matter and spirit, however, we must go beyond mere intellect and open ourselves to what Jung (1971) called introverted intuition. In the Orphic, Pythagorean, and Platonic tradition, the symbolism of numbers is particularly important and it establishes the priority of arithmetic in relation to geometry, music, and astronomy (TAYLOR, 1932). The universe is conceived as a monad composed of countless other monads as its parts. In contrast to the monad, the dyad symbolized division, separation from God, strife, illusion, ignorance and unhappiness. In other words, the opposition between matter and spirit can be dissolved alchemically in a neutral monism that affirms them both while granting each their due. Different types of substance interpenetrate and thus make possible causal relations unsuspected by persons intellectually confined to the material world (HEINDEL, 2011). Both Nāda Yoga (HERSEY, 2013) and Vibrational Medicine (GERBER, 2001) share a Pythagorean concern for harmony in a sense that goes beyond the auditory frequencies expected in music making.

\section{Schoenberg: Cain versus Seth}

Although we have overcome (or sublated) the opposition between matter and spirit by means of a deep intuitionist neutral monism, we have yet to show how it played out in Schoenberg's life as an individual. The main question concerns whether, at the spiritual and symbolic level, Schoenberg should be categorized as a Cainian or as a Sethian. At first glance, one might be tempted to regard him as a Cainian because he further developed Josef Matthias Hauer's twelve-tone method. However, upon further reflection as well as data gathering, the case for Schoenberg as a Sethian becomes stronger than 
might be expected. For this, one must be ready to go beyond the letter, or the notes for that matter, and follow the resonance of his spirit in his works as a composer, painter, theoretician and essayist. His concern for faith and spirituality becomes even clearer when contrasted with the materialism (or opportunism?) of his supporter but also critic Theodor Adorno (2006). While Schoenberg's disdain for Adorno is well documented, an attempt to explore its spiritual overtones is worthwhile to provide some otherwise unavailable insight.

As Horton (2005) acknowledges, resistance towards musical modernism, including Schoenberg's music, has grown recently and has gained more solid philosophical support due to critiques by Scruton (1997), Taruskin (2004), Etter (2001) and others. The simple fact is that modernism has basically failed to attract mainstream audiences. On the positive side, modern works can at least claim to sound different and thus present themselves as original departures from their predecessors. Besides that, they have enriched the genre of horror movie music.

Sowinska-Fruhtrun (2017) argues that atonal and twelve-tone techniques arose from a utopian way of thinking that ended in frustration. By emphasizing the idea of equality among the twelve tones, Schoenberg challenged listeners not so much because of the number of liberated dissonances, but because he removed any sense of a harmonic center. Scruton (1997) submits that the technique's permutational character can at best confer an intellectual coherence to the music, but not an audible coherence that is typical of prolongational methods. Scruton (1997) and Boghossian (2002) mention Schoenberg's (1950) negative view that the diminished seventh chord had by then become a cliché, but agree that the variability of historical musical contexts disallows such blanket judgments. In fact, by itself, the technique has proven unable to generate works with distinct expression, sounding always the same, unpleasant, boring and cacophonic. In this sense, twelve-tone technique may be viewed as reductionist because it focuses on notes, which is not why people take an interest in music. It is insufficient, unnecessary, and ineffective to produce good music. Taruskin (2004) charges its advocates with committing a poietic fallacy, in which the only thing that matters in music appreciation would be the composer's intervention. As Sowinska-Fruhtrun reminds us, Thomas Mann associated twelve-tone technique in Doctor Faustus to nihilism (loss of meaning) and totalitarianism (obsession with control, imposition of new standards on composers, and total disregard 
for the audience). Dahlhaus (1989) went further and considered Schoenberg's attempt to cancel the tonal order from 1907 onwards as tantamount to committing an unjustifiable act of aggression against musical culture.

In this way, Schoenberg came to be seen as a major player in the intentional disruption of the European soundscape and musical lifeword. After the collapse of the common practice period, at least six domains became discernible: classical (including opera, lied, instrumental); avantgarde; jazz; folk and ethnic music; commercial entertainment; and functional music (therapy, muzak). However, this post-traumatic fragmentation has proven to be stable. Cross-over attempts between these domains have either failed or found limited success.

The ideological dimension of Schoenberg's work has generated increasing scholarly interest (CROSS; BERMAN, 2000). Taruskin (1984) and Gur (2011) identify a significant influence of Hegelianism, in which Spirit (Geist, in German) evolves by overcoming oppositions that transform previous conditions into a new state. In spite of Marxist claims to the contrary, Hegel's thought cannot be reduced to a materialist conception because that would require the elimination of one half of the spirit-matter dialectical couple. Although logically confusing from an intellectualist perspective, Hegelianism provides a dynamic approach to reality as a whole. While Gur (2012) explores the idea of progress, Sowinska-Fruhtrun (2017) emphasizes the utopian dimension in Schoenberg's view not only of musical history, but also of his place in it. Boulez (1986) thoughtfully suggests that this attempt to determine his own place in history may have harmed Schoenberg's creativity because it distracted him from living intensely in the moment, which was when he produced his best work.

Schoenberg (1983) rejected aesthetics for being a subjective habit listeners had no right to use to restrict composers' experimentation. This delegitimized music criticism. Claims to technical innovation could henceforth be used by composers to confound critics. In this manner, he was revolutionary, but at the same time presented himself as a stalwart defender of the German musical tradition, whose supremacy he wanted to assure for the next hundred years. Boulez (1974) sees this as part of a dualistic personality. Others may interpret this behavior less charitably, suggesting that Schoenberg acted as a conservative-revolutionary double agent, only to more effectively subvert the moral and 
musical order of the day. According to informal assessments using current theories of personality, it is possible that Schoenberg may have been a Type 5 in the Enneagram of personality (CHESTNUT, 2013) or an INTJ in the Myers-Briggs Type Indicator (MYERS; MYERS, 1980), which relies strongly on introverted intuition as a dominant cognitive function. He also experienced a serious personal tragedy in 1907 when his wife Mathilde briefly left him for their common friend, the painter Richard Gerstl, who later committed suicide (ETTER, 2001). Erwartung, Op. 17 (1909) and Die glückliche Hand, Op. 18 (1913) clearly reflect the impact of these events, made only more dramatic by the influence of Otto Weininger, who committed suicide one year after converting to Christianity in 1902.

From a therapeutic perspective, Mattos (2021) raises the question concerning how Schoenberg's music can contribute to a music-centered music therapy. From the point of view of Alexander Technique, however, most kinds of discomfort, pain, stress, sadness, and disharmony are unhealthy and should be avoided. According to Scruton (1997), twelve-tone technique, as a kind of heartless formalism, gratified a need for pseudoscientific validation in a profoundly materialistic culture in which narcissistic individuals wanted to seem original and independent regardless of what that meant in a wider social context.

In light of these psychological issues, it is not surprising that Schoenberg sought solace in spiritualist circles (COVACH, 1992, 1995, 1996) (ROSS, 2017). Etter (2001) details Schoenberg's involvement with Theosophy. Covach (1992) documents his relations to Swedenborg, Goethe, Schopenhauer, Balzac, Rudolf Steiner, and Kandinsky. It is also worth noting that "Farben" from his Five orchestral pieces, Op. 16 would later on influence meditative drone music of La Monte Young (GRIMSHAW, 2011) (MERTENS, 2007). This is remarkable because dodecaphony is musically committed to avoiding the gravitational effects generated by a tonal center, but what mattered to the minimalists lied beyond the notes.

The spiritualist influence on Schoenberg also had an impact on his theorizing. Covach (1996) argues that Schoenberg's reliance on intuitive contemplation made it impossible for him to define what he meant by a musical thought (in German, der musikalische Gedanke). The very quest for artistic means of expression was intrinsically 
related to the intuitionist view that verbal language was inherently unable to express essential truth (COVACH, 1992). Ross (2017) mentions Schoenberg's attempt to treat harmonic material alchemically. Comparing the relation between major and minor chords to that between male and female, he sought new chords that could function as hermaphrodites. Covach (1995) claims that Schoenberg felt challenged by the need to bring forth a spiritual essence in music and that this had to happen by creating an alternative reality drawn from the previous world of German musical tradition. This new world would contrast from the older one because of its pantonality.

Ross (2017) makes an important point concerning revisionism in the historiography of modernism after 1945, in which any reference to mystical and esoteric dimensions was avoided. Instead, an attempt was made to present modernism in a way that conformed to the prejudices of scientific materialism. Hence Adorno's talk about "musical material" and Greenberg's about the painting's "medium." Convenient as that may be, Ross notes that this materialistic rewriting of history makes it impossible to properly appreciate what Schoenberg and Kandinsky were aiming for on the spiritual level. Not surprisingly, this may also explain Schoenberg's antipathy for Adorno.

At first glance, it might be thought that creative artists would welcome critics and theorists who offer to support them in writing. In contrast to performing artists, who are faced with other, more practical, challenges, composers after Schumann have had to increasingly engage with their public on a more theoretical level. By the time Liszt and Wagner came around, this kind of meta-compositional discourse had become such a full fledged propagandistic endeavor that it could justify recruiting a young promising academic like Nietzsche. However, in his review of the correspondence between Adorno and Alban Berg, Dwyer (2007) depicts a situation quite different from the one between Wagner and Nietzsche. While Nietzsche venerated Wagner and relinquished any ambitions to pursue composition, Adorno aspired to become prominent both as a philosopher and a composer. Since Schoenberg was unavailable, he approached Berg, who realized his potential as a publicist. However, Schoenberg stayed true to Beethoven's principle that music should be able to stand on its own merits and not depend on verbal justification. Moreover, he was perfectly able to defend his work in his own writing (SCHOENBERG, 1950), notwithstanding some struggle with clarifying fundamental notions such as that of a musical idea (COVACH, 1992). In spite of Berg's mediation, 
Schoenberg could see through the overambitious Adorno, whose dogmatic Marxist and Freudian views had absolutely nothing to do with his own philosophical and spiritual inclinations (JEREMIĆ-MOLNAR; MOLNAR, 2009). Any materialistic perspective that purports to engage with art will inevitably stumble on the impossibility of conferring any deep sense to terms related to its spiritual dimension. Adorno's dialectical analyses can neither address such issues nor go beyond mere wordplay. Although he cannot be denied a grounding in musical practice and theory, he produced sociological non-sequiturs and associations that can be seen as pedantic, wild, and confused. In this sense, as a good materialist, he contributed to maintaining the current negative connotation of the terms 'speculative' and 'dialectics'. An example of the harm caused by Adorno's rejection of reconciliation in dialectics is given by his follower Whittal (1999), who takes Taruskin and Scruton to task for quite reasonably demanding that continuity in the musical tradition be preserved as a way to keep it alive and to assess the originality of new works.

Schoenberg's misgivings against Adorno were later confirmed in his own eyes by his misunderstanding with Thomas Mann concerning his novel Doctor Faustus, published in 1947 (CALICO, 2014) (BROWN, 2014) (SOWINSKA-FRUHTRUN, 2017). Once again, the source of the problem does not seem to lie in the composer, but rather in the two writers. Not only did Adorno provide insider knowledge to Mann on compositional technique, but Mann himself liked to exploit in his writing a powerful tension between fiction, which his novel was supposed to be, and a reality which, however, included living persons with reputations to protect. Although this may have been psychologically stimulating for him as a writer and could generate wider reader interest, it did feed into an uncontrollable wave of gossip and prying curiosity that could border on the intolerable. In Schoenberg's case, it went so far as to give rise to a potential claim that Mann had developed twelve-tone technique himself. To add insult to injury, Mann's depiction of the main character Adrian Leverkühn and the whole situation surrounding him was not particularly positive. Regardless of how one might judge the bitter fruits of Schoenberg's pantonal experimentations and regardless of whether he harbored an antisocial streak in leading the charge against tonality, it is hard to see why anyone would side with Adorno or Mann on this specific issue. It is interesting to note, however, that from the perspective of Rudolf Steiner's Ahriman-Christ-Lucifer distinction mentioned earlier, Adorno the materialist can be said to represent the 
Ahrimanic force, while Mann the fictionalist stands in for the Luciferian force, leaving Schoenberg, despite his return to Judaism, in what would appear to be the Christic position. Under Max Heindel's distinction between Cain and Seth, historically replayed in the dispute between Hiram Abif and Solomon for the favor of the Queen of Sheba, it would appear that Schoenberg's pantonal project reenacts Hiram's molten sea.

\section{Concluding Remarks}

We are born into the world under material conditions that result from our previous choices, and spiritual development requires that we struggle to overcome them. Deep inside each one of us, the influences of Cain, Abel and Seth fight to gain the upper hand. In Schoenberg's case, although he became notorious and has been vilified for his Cainian accomplishments, in our view, it was the Sethian side of him that won out in the end. This is borne out by his lifelong spiritual and religious journey, which included a sincere effort to convert to German Protestantism and to defend Deutschtum until a regrettable incident in 1921 convinced him that assimilation was pointless (BROWN, 2014). Further research on the development of his religious and political ideas (CROSS; BERMAN, 2000) has shown that in his mature years Schoenberg had achieved a wider vision of life that went beyond musical technicism. This yearning for greater spiritual meaning can be traced back to his earlier years under the influence of Wagner, Brahms, Mahler, and Richard Strauss, when he composed Verklärte Nacht, Op. 4 (1899), Pelleas und Melisande, Op. 5 (1903), and the Gurre-Lieder (1911). It is perhaps to this youthful phase that one should turn to find the positive spiritual dimension within the uncertain and the controversial in his work.

\section{References}

ADORNO, Theodor W. Philosophy of New Music. Minneapolis: University of Minnesota, 2006.

BOGHOSSIAN, Paul A. On Hearing the Music in the Sound: Scruton on Musical Expression. The Journal of Aesthetics and Art Criticism, v. 60, n. 1, p. 49-55, 2002. Disponível em: https://www.jstor.org/stable/1519973. Acesso em: 11 nov. 2021.

BOULEZ, Pierre. Schönberg le mal-aimé?. In: Orientations: Collected Writings by Pierre Boulez. Cambridge, MA: Harvard University Press, 1986. p. 325-329. 
BROWN, Julie. Schoenberg and Redemption. Cambridge, UK: Cambridge University Press, 2014.

BRUHN, Herbert et al. (eds.). Musikpsychologie: Ein Handbuch. Hamburg: Rowohlt, 1994.

BRUHN, Herbert. Musikpsychologie: Das Neue Handbuch. Reinbek bei Hamburg: Rowohlt Taschenbuch Verlag, 2011.

BUNGE, Mario. Scientific Materialism. Dordrecht: Reidel, 1981.

CALICO, Joy Haslam. Arnold Schoenberg's "A Survivor from Warsaw" in Postwar Europe. Berkeley: University of California Press, 2014.

CHESTNUT, Beatrice. The Complete Enneagram: 27 Paths to Greater Self-Knowledge. Berkeley, CA: She Writes Press, 2013.

COVACH, John. Schoenberg and The Occult: Some Reflections on the Musical Idea. Theory and Practice, NY, v. 17, p. 103-118, 1992. Disponível em: http://www.jstor.org/stable/41054262. Accesso em: 10 set. 2021.

COVACH, John. Schoenberg's Turn to an "Other" World. Music Theory Online, [s. 1.], v. 1, n. 5, p. 1-11, 1995. Disponível em: https://mtosmt.org/issues/mto.95.1.5/mto.95.1.5.covach.html. Acesso em: 10 set. 2021.

COVACH, John. The Sources of Schoenberg's "Aesthetic Theology". 19th-Century Music, CA, v. 19 , n. 3, p. 252-262, 1996. Disponível em: http://www.jstor.org/stable/746221. Acesso em: 10 set. 2021 .

CROSS, Charlotte M.; BERMAN, Russell A. (ed.). Political and Religious Ideas in the Works of Arnold Schoenberg. NY: Garland Publishing, 2000.

DAHLHAUS, Carl. Schoenberg and the New Music. Cambridge, UK: Cambridge University Press, 1989.

DWYER, Benjamin. 'O Master of Secret Configurations': Reflections on the Adorno/Berg Correspondence. The Musical Times, v. 148, n. 1899, pp. 89-102, 2007. Disponível em: https://www.jstor.org/stable/25434461 Acesso em: 10 set. 2021.

ETTER, Brian. From Classicism to Modernism: Western Musical Culture and the Metaphysics of Order. London: Taylor \& Francis, 2001. 274 p. ISBN 9781315185767. DOI doi.org/10.4324/9781315185767. Disponível em: https://www.taylorfrancis.com/books/mono/10.4324/9781315185767/classicism-modernismbrian-etter?refId=d3572613-31d2-4ab4-9a7c-734c81643c13. Acesso em: 10 set. 2021.

FEYERABEND, Paul. How To Defend Society Against Science. Radical Philosophy, London, v. 3, n. 11, 1975. Disponível em: https://www.radicalphilosophyarchive.com/issuefiles/rp11_article1_defendsocietyagainstscience_feyerabend.pdf. Acesso em: 11 nov. 2021.

FEYERABEND, Paul. Science in a Free Society. London: NLB, 1978.

FEYERABEND, Paul. Theoreticians, Artists and Artisans. Leonardo, [s. 1.], v. 29, n. 1, p. 23-28, 1996. Disponível em: http://www.jstor.org/stable/1576272. Acesso em: 11 nov. 2021. 
GERBER, Richard. Vibrational medicine. The \#1 handbook of subtle-energy therapies. Rochester, VT: Inner Traditions/Bear, 2001.

GRIMSHAW, Jeremy. Draw a Straight Line and Follow It: The Music and Mysticism of LaMonte Young. New York, NY: Oxford University Press, 2011.

GUR, Golan. The Spectre of the End: Musical Avant-Gardism and the Philosophical Turn. International Review of the Aesthetics and Sociology of Music, v. 42, n. 2, p. 267-284, 2011. Disponível em: https://www.jstor.org/stable/41337861 Acesso em: 10 set. 2021.

GUR, Golan. 'Arnold Schoenberg and the Ideology of Progress in Twentieth-Century Musical Thinking', Muzykalia, v. XIII Judaica, n. 4, p. 1-11, 2012. Disponível em: http://www.searchnewmusic.org/gur.pdf ou http://demusica.edu.pl/muzykalia-xiii-judaica-4/ Acesso em: 10 set. 2021.

HABERMAS, Jürgen. Theorie des kommunikativen Handelns. Frankfurt am Main: Suhrkamp, 1981.

HACKER, Peter M. S. et al. Neuroscience and Philosophy: Brain, Mind, and Language. New York: Columbia University Press, 2009.

HATFIELD, Gary. Helmholtz and Philosophy: Science, Perception, and Metaphysics, with Variations on Some Fichtean Themes. Journal for the History of Analytical Philosophy, v. 6, n. 3, p. 11-41, 2018.

HEINDEL, Max. Freemasonry and Catholicism. 9th Edition reprint. Oceanside, CA: Rosicrucian Fellowship, 1978.

HEINDEL, Max. The Rosicrucian Cosmo Conception. [s.1.]: Pacific Publishing Studio, 2011.

HERSEY, Baird. The Practice of Nada Yoga: Meditation on the Inner Sacred Sound. Rochester, VT, USA \& Toronto, Canada: Inner Traditions, 2013.

HORTON, Julian. Review: Schoenberg and the 'Moment of German Music'. Music Analysis, v. 24, n. 1/2, p. 235-262, 2005. Disponível em: https://www.jstor.org/stable/3840781

JEREMIĆ-MOLNAR, Dragana; MOLNAR, Aleksandar. Adorno's Marxism Versus Schoenberg's Judaism: Ideological Foundations of Adorno's Sociological Approach to Schoenberg's Dodecaphonic Music. Sociologija, Belgrade, v. 51, n. 1, p. 45-54, 2009. DOI 10.2298/SOC0901045J. Disponível em: http://www.doiserbia.nb.rs/img/doi/00380318/2009/0038-03180901045J.pdf. Acesso em: 11 nov. 2021.

JUNG, Carl G. Psychological Types. London: Routledge, 1971.

MATTOS, André Brandalise. Music-centered Music Therapy: Contributions for the Present and Future of Music Therapy. Voices: A World Forum For Music Therapy, Bergen, Norway, [s.d.]. Disponível em: https://voices.no/index.php/voices/article/view/1832/1595. Acesso em: 8 set. 2021.

MERTENS, Wim. American minimal music. London: Kahn \& Avewrill, 2007.

MOSER, Paul K.(ed.) A priori knowledge. Oxford: OUP, 1987. 
MYERS, Isabel B.; MYERS, Peter B. Gifts Differing: Understanding personality type. Mountain View, CA: Davies-Black Publishing, 1980.

ROS, Arno. Begründung und Begriff. Wandlungen des Verständnisses begrifflicher Argumentationen. 3 vols., Hamburg: Felix Meiner, 1990.

ROS, Arno. Materie und Geist. Eine philosophische Untersuchung. Paderborn: Mentis, 2005.

ROSS, Alex. The Occult Roots of Modernism. The New Yorker, NY, 19 jun. 2017. Disponível em: https://www.newyorker.com/magazine/2017/06/26/the-occult-roots-of-modernism. Acesso em: 10 set. 2021.

SCHOENBERG, Arnold. Style and Idea. NY: Philosophical Library/Open Road, 1950.

SCHOENBERG, Arnold. Theory of Harmony. Berkeley \& Los Angeles, CA: University of California, 1983.

SCRUTON, Roger. The Aesthetics of Music. Oxford: Oxford University Press, 1997.

SHAFER, R. Murray. The Soundscape: Our Sonic Environment and the Tuning of the World. Rochester, VT, USA: Inner Traditions, 1994.

SOWINSKA-FRUHTRUN, Iwona. Arnold Schoenberg's Dodecaphonic Method as a Representation of an Artistic Utopia. In: OLKUSZ, K.; KLOSINSKI, M.; MAJ, K. M. More after More: Essays Commemorating the Five-Hundredth Anniversary of Thomas More's "Utopia". Frontiers of Nowhere (v. 1), Kraków: Facta Ficta, 2017, cap. 25, p. 394-405.

STEINER, Rudolf. Christ in Relation to Lucifer and Ahriman: A Lecture at Linz, May 18, 1915 GA 159. Hudson, N.Y.: The Anthroposophic Press, 1978. Disponível em: https://wn.rsarchive.org/Lectures/ChrLuc index.html. Acesso em: 11 nov. 2021.

TARUSKIN, Richard. The Authenticity Movement Can Become a Positivistic Purgatory, Literalistic and Dehumanizing'. Early Music, v. 12, n. 1, p. 3-12, 1984. Disponível em: https://www.jstor.org/stable/3127146. Acesso em: 11 nov. 2021.

TARUSKIN, Richard. The Poietic Fallacy. The Musical Times, v. 145, n. 1886, p. 7-34, 2004. Disponível em: https://www.jstor.org/stable/4149092. Acesso em: 11 nov. 2021.

TAYLOR, Thomas. The Theoretic Arithmetic of the Pythagoreans. Introductory Essay by Manly P. Hall. Los Angeles, CA: The Phoenix Press, 1934.

WHITTAL, Arnold. Twentieth-Century Music in Retrospect: Fulfilment or Betrayal?. The Musical Times, v. 140, n. 1869, p. 11-21, 1999. Disponível em: https://www.jstor.org/stable/1004517. Acesso em: 11 nov. 2021.

YATES, Frances A. The Rosicrucian Enlightenment. London \& NY: Routledge, 1972. 